\section{Sykehuset Telemark}

Sykehuset Telemark er et allsidig akuttsykehus, der endringer i befolkningen og befolkningens behov blir tatt på alvor. Tøff satsing på kompetente og sterke fagmiljøer har medført en omfattende endring av sykehusstrukturen i fylket.

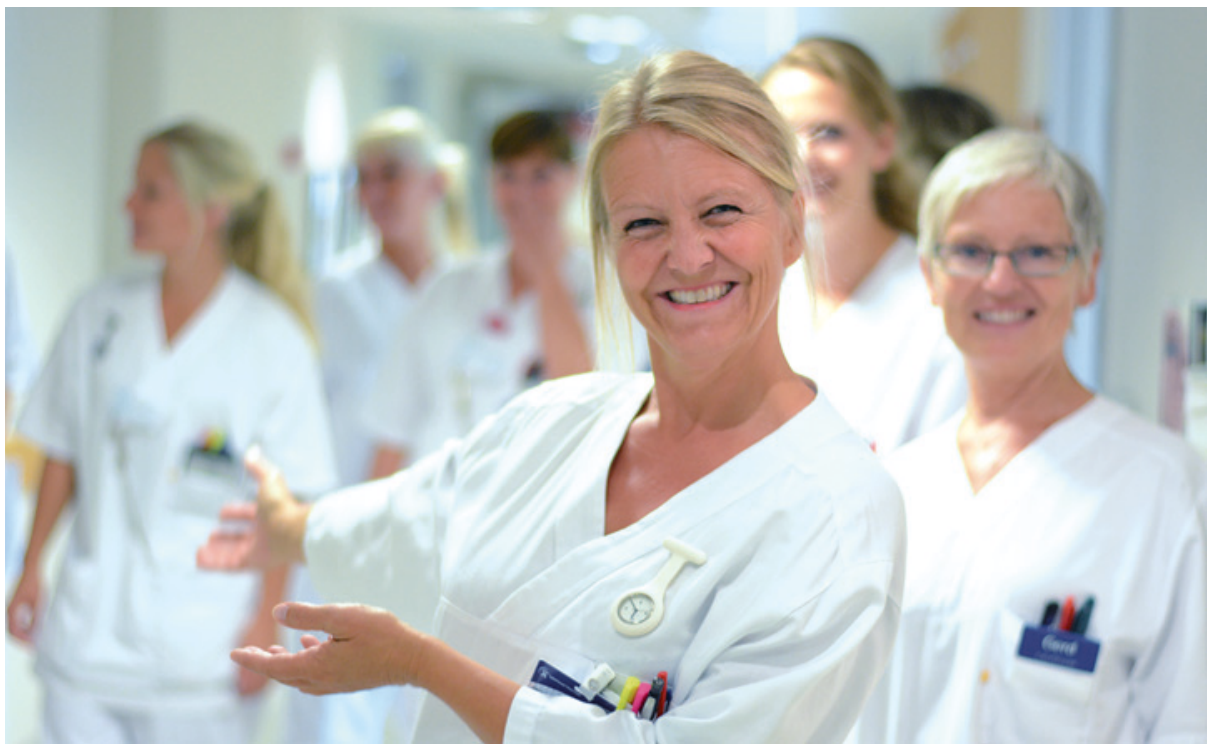

Foto: Sykehuset Telemark

Sykehuset Telemark har to akuttmottak, ett i Skien og ett på Notodden. Akuttmottaket i Skien er fra høsten 2014 bemannet med spesialiserte akuttoverleger i front. Her skal pasienten møte den beste kompetansen fra første stund på sykehuset når det haster med riktig diagnose og behandling.

Sykehuset har hovedsete i Skien, både for somatikk og psykiatri. I tillegg er det dagsykehus i Porsgrunn med dagkirurgi og poliklinikker. På Notodden er det lokalsykehusfunksjon. I 2014-15 iverksetter Sykehuset Telemark en vedtatt utviklingsplan som medfører store endringer i drift og struktur. Sykehusene på Rjukan og i Kragerø omstilles til å bli dagsykehus med primært polikliniske tilbud og lokalt tilpasset tilbud til kronikere. I utviklingsplanen legges det også opp til klinikkstrukturer på tvers av geografi, med faglighet som premissgiver. Til tross for samling av enkelte tilbud, har sykehuset fortsatt en desentralisert struktur, særlig innen psykiatri.

Sykehuset Telemark er i sykehusområde med Sykehuset i Vestfold og har regionfunksjon innen plastikkirurgi, arbeidsmedisin og assistert befruktning. Sykehuset Telemark har også høyt spesialisert kompetanse innen genetikk.

Ved utgangen av 2014 har Sykehuset Telemark drøyt 3000 årsverk, et budsjett på rundt 3,6 milliarder kroner og sykefravær rundt 6,5\%. Her finnes også bedriftsidrettslag og sykehusrevy.

Telemark og Grenlandsområdet har et variert næringsliv med gode skole- og utdanningsmuligheter på høyskolenivå. Boligmarkedet er svært gunstig for etablerere sammenliknet med pressområdene nærmere Oslo, samtidig ligger Notodden og Skien bare 1,5-2 timer fra hovedstaden. Det er kort vei til flyplassen Torp, og Telemark fylke er kjent for sin fantastiske natur og mulighet for friluftsliv fra kyst til vidde.

For mer informasjon om Sykehuset Telemark, se www.sthf.no.
26.01.

FRIST FOR REGISTRERING AV ANNONSER TIL NR. 3/2015 PÅ LEGEJOBBER.NO

\section{Om Legejobber.no}

Legejobber.no er Tidsskriftets stillingsportal for leger og for stillingsannonsører.

Som annonsør kan du nå bestille annonsen døgnet rundt via Legejobber.no. Du registrerer nettannonsen og papirannonsen samtidig.

Som jobbsøker kan du på Legejobber.no enkelt søke etter ledige jobber etter spesialitet, geografisk område eller i fritekst.

Ønsker du å motta varsel om ledige stillinger innenfor et bestemt område?

På Legejobber.no kan du abonnere på ledige stillinger.

\section{Priser på stillingsannonser 2015}

* Gjelder for kombinasjon papir/nett.

Format

Størrelse

1/1 side

$185 \times 245$

Pris svart-hvitt

32200

Pris 4 farger

35400

$1 / 2 \mathrm{~s}$. liggende

$185 \times 112$

Pris svart-hvitt

17300

Pris 4 farger

20400

1/2 s. stående

$90 \times 245$

Pris svart-hvitt

17300

Pris 4 farger

20400

$1 / 4$ side

$90 \times 112$

Pris svart-hvitt

9200

Pris 4 farger

11200

$1 / 8$ side

$90 \times 45$

Pris svart-hvitt

7000

Pris 4 farger 